\title{
Experiential value: a hierarchical model, the impact on e-loyalty and a customer typology
}

Citation for published version (APA):

van Oppen, C. A. M. L., Odekerken-Schröder, G. J., \& Wetzels, M. G. M. (2005). Experiential value: a hierarchical model, the impact on e-loyalty and a customer typology. METEOR, Maastricht University School of Business and Economics. METEOR Research Memorandum No. 017 https://doi.org/10.26481/umamet.2005017

Document status and date:

Published: 01/01/2005

DOI:

10.26481/umamet.2005017

Document Version:

Publisher's PDF, also known as Version of record

\section{Please check the document version of this publication:}

- A submitted manuscript is the version of the article upon submission and before peer-review. There can be important differences between the submitted version and the official published version of record. People interested in the research are advised to contact the author for the final version of the publication, or visit the DOI to the publisher's website.

- The final author version and the galley proof are versions of the publication after peer review.

- The final published version features the final layout of the paper including the volume, issue and page numbers.

Link to publication

\footnotetext{
General rights rights.

- You may freely distribute the URL identifying the publication in the public portal. please follow below link for the End User Agreement:

www.umlib.nl/taverne-license

Take down policy

If you believe that this document breaches copyright please contact us at:

repository@maastrichtuniversity.nl

providing details and we will investigate your claim.
}

Copyright and moral rights for the publications made accessible in the public portal are retained by the authors and/or other copyright owners and it is a condition of accessing publications that users recognise and abide by the legal requirements associated with these

- Users may download and print one copy of any publication from the public portal for the purpose of private study or research.

- You may not further distribute the material or use it for any profit-making activity or commercial gain

If the publication is distributed under the terms of Article $25 \mathrm{fa}$ of the Dutch Copyright Act, indicated by the "Taverne" license above, 


\title{
EXPERIENTIAL VALUE: A HIERARCHICAL MODEL, THE IMPACT ON E-LOYALTY AND A CUSTOMER TYPOLOGY
}

Version June 7, 2005

Please do not refer to or quote from this manuscript without the explicit permission of the authors.

\section{Claudia van Oppen ${ }^{1}$}

Gaby Odekerken-Schröder ${ }^{2}$

\author{
Martin Wetzels ${ }^{3}$
}

\footnotetext{
1 PhD Student, Department of Marketing, Maastricht University, Tongersestraat 53, 6211 LM Maastricht, the Netherlands, phone: +31 43 3883861; fax: +31 43 3884918; e-mail: c.vanoppen@mw.unimaas.nl.

2 Associate Professor, Department of Marketing, Maastricht University, Tongersestraat 53, 6211 LM Maastricht, the Netherlands, phone: +31 43 3883618; fax: +31 43 3884918; e-mail: g.schroder@mw.unimaas.nl.

3 Professor of Marketing, Department of Organization Science and Marketing, Eindhoven University of Technology, Den Dolech 2, 5600 MB Eindhoven, the Netherlands, phone: +3140 2473680, fax: +31140 2465949, email: m.g.m.wetzels@tm.tue.nl.
} 


\title{
EXPERIENTIAL VALUE: A HIERARCHICAL MODEL, THE IMPACT ON E-LOYALTY AND A CUSTOMER TYPOLOGY
}

\begin{abstract}
The main objective of this study is to empirically test a fourth-order hierarchical model of experiential value in an online book and CD setting. In addition, we provide empirical evidence for the role of hedonic and utilitarian value components in creating attitudinal and behavioral loyalty. Finally, we develop an online customer typology, based on the underlying value sources. Based on a sample of 190 visitors of online book and CD retailers, we used PLS to test a third and fourth order hierarchical model of experiential value, emphasizing a hedonic (intrinsic) and utilitarian (extrinsic) value component and the existence of the holistic concept of experiential value. Our results demonstrate that experiential value consists of the third order components hedonic (intrinsic) and utilitarian (extrinsic) value. Both value aspects impact attitudinal loyalty ultimately leading to behavioral loyalty which is also directly affected by utilitarian value. Finally, a nonhierarchical (k-means) cluster analysis identified four segments of online visitors: hedonists, utilitarians, active negativists, and reactive positivists.
\end{abstract}




\section{INTRODUCTION}

The Internet has emerged as a hyper-competitive market space, where firms find it increasingly difficult to sustain competitive advantage (Verona and Prandelli 2002). Since competitors are so near and price comparisons made so easy, it is essential to attract and keep visitors to specific sites and convince them to return on a regular basis. Previous research has shown that loyal customers buy more of a company's products, are cheaper to serve, are less sensitive to price, and attract additional customers through positive word-of-mouth (Reichheld and Schefter 2000). Recent research on loyal customers online demonstrated that these loyal customers are highly profitable (Nielsen 1997; Scheraga 2000). However, there is still a lack of research on drivers of online loyalty (e.g. Gans 2002; Harris and Goode 2004). Novak, Hoffman and Yung (2000) acknowledge that it is of crucial importance to create a strong online experience, though knowledge on factors contributing to this strong online experience is largely lacking. In a similar vein, Kim and Stoel (2004) argue that consumers must value their online experience; otherwise they will not become loyal. In an offline setting value is generally accepted as an antecedent of loyalty (e.g. Peterson 1995; Sirdeshmukh, Singh, and Sabol 2002). In 1997, Woodruff (p. 140) already claimed that "the issue does not seem to be whether an organization should compete on customer value delivery, but rather how it should do it." Zeithaml (1988) identified four common uses of the term value: (1) value as price, (2) value as 'what I get for what I give', (3) value as the trade-off between price and quality, and (4) value as an overall assessment of subjective worth. While the first three value perspectives are rather objective, the latter is more subjective in nature referring to all factors that make up the experience (Zeithaml 1988).

In an online context, website characteristics received the most attention as potential drivers of e-loyalty (e.g. Srinivasan, Anderson and Ponnavolu 2002; Wolfinbarger and Gilly 2003). Novak, Hoffman and Yung (2000) found empirical evidence for the impact of flow, 
which can be seen as an optimal experience (Csikszentmihalyi 1997), on positive affect and exploratory behavior. Recently Chiou (2004) found empirical evidence for the positive impact of customer perceived value on loyalty intentions towards Internet Service Providers. In a similar vein, Luo and Seyedian (2004) empirically demonstrated the positive impact of perceived site value on perceived satisfaction in the context of Internet storefront sites selling books, CDs, computers, and traveling. Apparently, the importance of customer value in an online context is gradually being recognized. In this respect, the work by Mathwick, Malhotra, and Rigdon $(2001 ; 2002)$ can be considered as a major step forward. They introduce, develop and test an experiential value scale, referring to an experience-based value concept. Experiential value is defined as "A perceived, relativistic preference for product attributes or service performances arising from interaction within a consumption setting that facilitates or blocks achievement of customer goals or purposes” (Mathwick, Malhotra, and Rigdon 2002, p. 53). While they provide conceptual support for a third and fourth order model of experiential value, in their empirical study they only test a second order model. Therefore, the main objective of our paper is to test a hierarchical model of experiential value and extend Mathwick, Malhotra, and Rigdon's (2001) model by providing empirical evidence for the third and fourth order model demonstrating that experience-based value online consists of a hedonic (intrinsic) and utilitarian (extrinsic) value component. Our second objective is to test whether these two components of experiential value impact attitudinal and behavioral loyalty online, as these insights would offer interesting insights for online retailers. The third objective of this paper is to use the underlying dimensions of experiential value to develop a typology of online customers enabling marketers to develop and target strategies and tactics to attract and maintain these individuals. 


\section{A HIERARCHICAL APPROACH TO EXPERIENTIAL VALUE}

Recently, the interest in the nature of multidimensional constructs has spawned a number of publications addressing the issue of typology for multidimensional constructs (Edwards, 2001; Edwards and Bagozzi, 2000; Law and Wong, 1999; Law et al., 1998; Schneider et al. 1996). Edwards (2001) distinguishes between two types of constructs on the basis of the relationship between the construct and its dimensions: (1) superordinate construct and (2) aggregate construct. For a superordinate construct a reflective relationship between the construct and its dimensions is assumed $\left(\mathrm{C} \rightarrow \mathrm{D}_{\mathrm{i}} ; \mathrm{C}=\right.$ Construct, $\mathrm{D}_{\mathrm{i}}=$ Dimension $\mathrm{i}$; Edwards and Bagozzi, 2000). For an aggregate construct a formative relationship between the construct and its dimensions is assumed $\left(\mathrm{D}_{\mathrm{i}} \rightarrow \mathrm{C} ; \mathrm{C}=\right.$ Construct, $\mathrm{D}_{\mathrm{i}}=$ Dimension $\mathrm{i}$; Edwards and Bagozzi, 2000). Law and Wong (1999) refer to these types respectively as factor view and composite view of a multidimensional construct.

Irrespective of terminology, Law et al. (1998) acknowledge that in the current literature many multidimensional constructs are developed without a clear specification of the relationships with their dimensions, leading to different interpretations. Mathwick et al. (2001) do not explicitly define the relationships between the different levels of experiential value. Since the model contains levels of a higher order than the second order, the typology of Edwards (2001) needs to be extended. At the second-order level (cf. Rindskopf and Rose, 1988) a reflective mode seems to be a plausible option and is supported by both the conceptualization and data analysis approach in Mathwick et al. (2001).

\section{Second Order Structure of Experiential Value}

Mathwick, Malhotra, and Rigdon (2001) base their conceptualization of experiential value on Holbrook (1994) and distinguish between intrinsic (hedonic) and extrinsic (utilitarian) value components and active and reactive sources of value on the other hand. In consumer behavior 
research consumers have been depicted as either 'problem solvers' or 'fun seekers', representing the utilitarian versus hedonic dichotomy (Hirschman and Holbrook 1982). In the retail literature this dichotomy is applied to distinguish between shopping motivations originating from viewing shopping as work versus viewing shopping as fun (Babin, Darden, and Griffin 1994). Also in an online context hedonic and utilitarian motivations seem to underlie online retail shopping behavior (Childers et al. 2001). Our dual characterization of components is consistent with these existing views on utilitarian versus hedonic motivations. With respect to the active and reactive sources of value, Holbrook (1994, p.43) defines the active dimension as 'a manipulation of the environment' and mentions playing a video game as an example. In the reactive dimension in contrast, the consumer mainly acts as a viewer and receiver instead of as an active participant. Mathwick, Malhotra and Rigdon (2001) distinguish playfulness, aesthetics, customer return on investment and service excellence as sources of value as can be seen in Figure 1.

\section{[INSERT FIGURE 1 ABOUT HERE]}

As can be seen, the hedonic (intrinsic) value dimension is composed of playfulness and aesthetics. Playfulness refers to the absorbing capacity of a website, making the consumer a co-producer of value, while aesthetics reflects the visual appeal of a website (Mathwick, Malhotra, and Rigdon 2001). The utilitarian (extrinsic) value dimension is composed of consumer return on investment (CROI) and service excellence. CROI denotes consumers' active investment of resources that might generate a benefit, whereas service excellence refers to active consumer responses expressing their appreciation of the delivered service (Mathwick, Malhotra, and Rigdon 2001). These second order concepts in turn entail several first order constructs. Playfulness involves enjoyment and escapism, aesthetics is composed of visual appeal and entertainment, customer return on investment is made up of economic 
value and efficiency, while they do not define first order concepts of service excellence (for more detailed information we refer to Mathwick, Malhotra and Rigdon 2001). As will be summarized in the next section, the hedonic versus utilitarian value dimensions are well established in the existing literature, and seem to offer a promising distinction in an online setting. In replicating Mathwick, Malhotra, and Rigdon's (2001) second order model of experiential value, we hypothesize:

$H_{1 a}:$ Visual appeal is positively associated with aesthetics

$H_{1 b}:$ Entertainment is positively associated with aesthetics

$H_{1 c}:$ Escapism is positively associated with playfulness

$H_{1 d}:$ Enjoyment is positively associated with playfulness

$H_{1 e}:$ Efficiency is positively associated with customer return on investment (CROI)

$H_{1 f:}$ Economic value is positively associated with customer return on investment (CROI)

\section{Third Order Structure of Experiential Value}

Holbrook (1994) elaborated on the nature of customer value and clearly distinguished four essential elements of customer value. First, he argues that customer value refers to a preference, which he describes as a 'favorable disposition, general liking, positive affect, judgment as being good, tendency to approach, pro versus con attitude' (Holbrook 1994, p.

27). Second, value involves a subject-object interaction, which means the interaction between a consumer and an object such as a product, service, event or idea. A third element of customer value entails its relativistic nature, referring to the fact that (1) consumers compare an object against other objects, (2) value is different among consumers, and (3) value differs within contexts. Fourth and finally, customer value is related to an experience rather than to the purchase of a product or service. Taking these four elements of customer value into consideration, in line with Mathwick, Malhotra and Rigdon (2001) we reason that Holbrook 
(1994) also argues for an experience-based value perspective. Although shopping research has a strong tradition in investigating utilitarian aspects of the shopping experience, hedonic aspects are currently recognized as being at least equally important in nowadays shopping environments (Arnold and Reynolds 2003). Likewise, Holbrook (1994) distinguishes a hedonic (intrinsic) and utilitarian (extrinsics) value component. In 1982 Holbrook and Hirschman already contrasted the information processing view (extrinsic) of consumer behavior to the experiential view (intrinsic) of consumer behavior. In line with their view, Havlena and Holbrook (1993) and Voss, Spangenberg and Grohmann (2003) refer to instrumental (utilitarian) consumer behavior and congenial consumer behavior (hedonic). Instrumental consumer behavior focuses on utilitarian aspects resulting from functions performed by an object, while congenial consumer behavior refers to hedonic gratification from sensory attributes. In a similar vein, Babin, Darden, and Griffin (1994) applied the hedonic and utilitarian consumer behavior to a shopping environment and distinguished between shopping as work (utilitarian) and shopping as fun (hedonic). They acknowledge that some consumers strive for utilitarian shopping value resulting from a conscious aim at intended outcomes, while others strive for hedonic shopping value emerging from emotional reward in terms of pleasure.

This rich body of literature gradually makes its entry in online settings (e.g. Novak, Hoffman and Duhachek 2003). Hoffman and Novak (1996) claim that the hedonic versus utilitarian distinction is especially important online, because this hedonic (intrinsic) value component is for many consumers even more important than the final utilitarian (extrinsic) outcome of their online behavior. Similarly, Childers et al. (2001, p. 513) explain that in the utilitarian view, consumers are concerned with purchasing products in an efficient and timely manner to achieve their goals with a minimum of irritation'. On the other hand, hedonic shoppers consider shopping an adventure, reflecting 'shopping's potential entertainment and 
the enjoyment resulting from the fun and play arising from the experience versus the achievement of any prespecified end goal' (Childers et al. 2001, p. 513). In the eminent Technology Acceptance Model (TAM) the distinction between perceived usefulness on the one hand and ease of use (Davis 1989), also implies a distinction between outcome and process, which is comparable to utilitarian and hedonic components of online shopping. Hence, Mathwick, Malhotra and Rigdon's (2001) explicit conceptual distinction between extrinsic (utilitarian) and intrinsic (hedonic) value in an online setting is not surprising. However, despite their conceptual distinction of a hedonic and utilitarian value dimension, they do not test this structure empirically. They only test the second order model, to the neglect of the hedonic (intrinsic) and utilitarian (extrinsic) value dimensions, which seem to be two crucial value dimensions in an online setting. While they position aesthetics and playfulness as hedonic (intrinsic) sources of experiential value in their typology of experiential value, because these sources of value are especially eminent for those consumers who shop for the sake of entertainment, they do not empirically test these sources of hedonic (intrinsic) value. Therefore we propose:

$H_{2 a}$ : Aesthetics is positively associated with hedonic (intrinsic) value $H_{2 b}$ : Playfulness is positively associated with hedonic (intrinsic) value In a similar vein, Mathwick, Malhotra, and Rigdon (2001) position service excellence and customer return on investment as utilitarian (extrinsic) sources of experiential value in their typology of experiential value. These value sources reflect the extent to which the retailer serves as a means to an end. However, Mathwick, Malhotra, and Rigdon (2001) do not empirically assess these sources of utilitarian (extrinsic) value either. Hence, we hypothesize: $H_{2 c}$ : Service excellence is positively associated with utilitarian (extrinsic) value $\mathrm{H}_{2 d}$ : Customer return on investment is positively associated with hedonic (intrinsic) value 


\section{Fourth Order Structure of Experiential Value}

Mathwick, Malhotra, and Rigdon's $(2001 ; 2002)$ conceptual work is based on the idea that an online experience can be assessed by means of experiential value expressing a perceived, relativistic preference, implying a holistic assessment of the experience. Although for practitioners it might be more helpful to gain knowledge on the differential impact of hedonic and utilitarian value on e-loyalty, research on experiential value might be pushed forward by empirically demonstrating the existence of the fourth order model of experiential value. Empirical support for a fourth order model would provide support for the conceptual ideas developed by Mathwick, Malhotra, and Rigdon (2001; 2002) meaning that an online experience consists of both a utilitarian and a hedonic dimension. Therefore we hypothesize: $H_{3 a} \quad H e d o n i c$ (intrinsic) value is positively associated with experiential value $H_{3 b} \quad$ Utilitarian (extrinsic) value is positively associated with experiential value

\section{EXPERIENTIAL VALUE AS A DRIVER OF E-LOYALTY}

In line with the commonly accepted research tradition initiated by Dick and Basu (1994) we make a distinction between attitudinal and behavioral aspects of customer (e-)loyalty and propose the conceptual model demonstrated in Figure 2. Therefore, we define e-loyalty in line with Srinivasan, Anderson, and Ponnavlu (2002) as a favorable attitude toward the website that results in repeat visiting behavior. Several recent studies investigated potential antecedents of loyalty in an online environment. Srinivasan, Anderson and Ponnavolu (2002) identified 8 factors potentially impacting e-loyalty (e.g. customization, convenience and choice). More traditional antecedents of loyalty that have been applied to an online context are trust and satisfaction (e.g., Chiou 2004; Harris and Goode 2004). As we described before, Mathwick, Malhotra, and Rigdon (2001) assessed the value dimensions (aesthetics and playfulness as dimensions of hedonic value; service excellence and customer return on 
investment -CROI- as dimensions of utilitarian value) as antecedents of attitudinal loyalty. In their Internet shopper sample, they only found support for the positive impact of CROI on attitudinal loyalty. However, in their sample of catalog shoppers they also found support for the impact of aesthetics on attitudinal loyalty. This latter finding implies that both a hedonic as well as a utilitarian aspect influences attitudinal loyalty positively. We agree with Chaudhuri and Holbrook (2001, p. 85) who reason that 'hedonic and utilitarian value correspond to the archetypal constructs of emotion and reason'. In their point of view, hedonic value (intrinsic) and utilitarian value (extrinsic) are orthogonal, implying that consumers' attitudes are best considered as resulting from some degree of both. Therefore we formulate the following hypotheses:

$H_{4 a}:$ Hedonic (Intrinsic) value has a positive impact on attitudinal loyalty

$H_{4 b}:$ Utilitarian (Extrinsic) value has a positive impact on attitudinal loyalty

Recently, Cotte et al. (2005) acknowledge that existing research either emphasizes the hedonic and utilitarian aspects of consumer experiences online (e.g. Childers et al. 2001) or customers' online behaviors (e.g. Emmanouilides and Hammond 2000), while the link between both value components and online behaviors is largely lacking (see Korgaonkar and Wolin 1999) for an exception. Therefore, we want to test whether:

$H_{4 c}$ : Hedonic (Intrinsic) value has a positive impact on behavioral loyalty $H_{4 d}$ : Utilitarian (Extrinsic) value has a positive impact on behavioral loyalty

As indicated by the value-attitude-behavior hierarchy (Homer and Kahle 1988), consumer attitudes influence their behavior. In the current study, we only assess behavioral intentions and consider these intentions as an indicator of behavioral loyalty. Many studies in the offline environment (Korgaonkar, Lund and Price 1985; Morgan and Hunt 1994) as well as in an 
online context (Mathwick, Malhotra and Rigdon 2001; Srinivasan, Anderson and Ponnavolu 2002) already demonstrated the positive impact of consumer attitudes on behavior. A consumer who experiences a positive attitude towards a website selling books and CD's will ceteris paribus be likely to have purchase intentions at this site. Therefore, we propose the following hypothesis:

$H_{5}:$ Attitudinal loyalty has a positive impact on behavioral loyalty.

[INSERT FIGURE 2 ABOUT HERE]

\section{CUSTOMER TYPOLOGY}

In the offline environment there is a rich tradition of consumer typologies (e.g. Westbrook and Black 1985). Since competition even seems to be fiercer in an online setting, understanding and targeting different customer segments also appears to be of vital importance online. Although still scarce, research on online customer typologies is developing gradually. Dahlén and Lange (2002) introduced a typology for online consumers which was based on several studies on existing shopping types in an offline setting. At the same time, Mathwick (2002) went beyond existing typologies and developed a new typology of online customers. However, despite her research on experiential value and its underlying dimensions, she did not use this knowledge to distinguish customer segments but rather used relational norms and online behavior as input for her typology. Recently, Rohm and Swaminathan (2004) developed a typology of online shoppers using shopping motivations as a basis, while Kau, Tang and Ghose (2004) built their typology of online shoppers on information seeking patterns, motivations and concerns for online shopping. Despite the acknowledged contribution of experiential value in an online context, to the best of our knowledge, there is no online customer typology built on the sources of experiential value. 
Therefore, we will develop a typology of online customers, by examining differences in the value sources visual appeal, entertainment, escapism, enjoyment, service excellence, efficiency, and economic value underlying experiential value.

\section{METHOD}

\section{Research Setting}

The conceptual model presented in figure 2 was tested in the context of online CD and bookstores. This context provided an appropriate test environment for several reasons. First, research indicated that $\mathrm{CD}$ and books are among the most frequently purchased items online (Kwak, Fox and Zinkhan 2002; Kim and Stoel 2004). Second, by addressing both the product category of CD's and books our study is not limited to only one dimension of experiential value, but can be expected to address both hedonic and utilitarian value components. Preliminary evidence for this assumption can be found in Kwak, Fox, and Zinkhan (2002) indicating that in purchasing books online, a high degree of information is required to purchase, while in the case of CD's/music a low degree of information is required.

\section{Sampling}

Data were collected in two stages. In the first stage, a sample of 1,000 individuals who participated in large online research panel, were selected. An e-mail invitation, containing an embedded URL link to the website hosting the survey was sent to each of the 1,000 potential respondents. Secondly, these potential respondents were asked to solicit adult family members and acquaintances to complete the questionnaire by employing a snowball sampling technique. In order to increase the response percentage, 5 cash incentives of $€ 12,50$ (app. $\$$ 12,50) were raffled. As a screening question we asked whether the respondent ever visited or purchased at an online book or CD store. If not, they were not included in our sample. The 
remaining respondents were asked to complete the questionnaire about their most frequently visited online book and CD store.

As a result, a total of 190 usable responses were obtained. Of the participants, $57.6 \%$ were female and $42.4 \%$ were male. $9.6 \%$ of the respondents were younger than $20,63.9 \%$ between 20 and 25 years, $19.5 \%$ between $26-30$ years, and $7 \%$ of the respondents were older than 30 years. Of the total sample population, $73.8 \%$ considered themselves as students, $21.9 \%$ as being employed, and $4.3 \%$ as "other".

\section{Measurement Instruments}

The online questionnaire consisted of multi-item scales from the existing literature. The experiential value scale we used was introduced by Mathwick, Malhotra, and Rigdon (2001). We applied the e-loyalty scale used by Srinivasan, Anderson and Ponnavolu (2002). All the items were measured on a 7-point Likert scale, ranging from 'strongly disagree' to 'strongly agree'. In addition, demographic information was collected.

Before the actual research was conducted, five graduate students of a large European university were asked to pre-test the questionnaire by paying specific attention to question content, wording, sequence, form and lay-out, question difficulty and instructions. During this pre-test, respondents were observed in order to monitor reactions and attitudes towards the questionnaire. Based on the problems identified by the respondents, several improvements to the questionnaire have been made.

\section{Data Analysis}

Higher-order models can be specified as an alternative to group-factor models (Bollen, 1989; Guinot et al., 2001; Marsh and Hocevar, 1985; Rindskopf and Rose, 1988). Basically, a 
higher-order model imposes an alternative structure on the pattern of correlations

(covariances) among the lower-order factors. As such the higher-order model represents a restriction of the group-factor model, which allows for correlated the lower-order factors (Rindskopf and Rose, 1988) ${ }^{4}$. For instance, a second-order model can be specified in two equations:

$$
\begin{aligned}
& y_{i}=\Lambda^{y} \eta_{j}+\varepsilon_{1} \\
& \eta_{j}=\Gamma \xi_{k}+\zeta_{j}
\end{aligned}
$$

The first equation defines the manifest variables in terms of the first-order factors and the second equation defines the first-order factors in terms of the second-order factors. Obviously, this hierarchical model can be extended to higher-order factors, such as third-order factors (cf. Marsh and Hocevar, 1985). For a third-order or fourth-order model equation 2 can be extended:

$$
\eta_{j}=B \eta_{j}+\Gamma \xi_{k}+\zeta_{j}
$$

The term $\mathrm{B} \eta_{\mathrm{j}}$ represents to the higher-order factors (and the related outcomes) from the firstorder to the $\mathrm{n}^{\text {th }}$ order except for the highest order factor at the construct level which is represented by the term $\Gamma \xi_{\mathrm{k}}$ (Edwards, 2001, Edwards and Bagozzi, 2000).

Hierarchical models using latent variables can be estimated using structural equation modeling (SEM). Essentially, both covariance-based SEM and component-based SEM, or partial least squares (PLS) can be employed to estimate the parameters in a hierarchical model (Guinot et al., 2001). Covariance-based SEM involves a number of restraints regarding distributional properties (multivariate normality), measurement level, sample size, model complexity, identification and factor indeterminacy (Chin 1998; Fornell and Bookstein, 1982;

As the second-order factor model is nested in the group-factor model, a $\Delta \chi^{2}$ can be used to compare model fit in covariance-based SEM (Rindskopf and Rose 1988). However, if the model fits the restricted model, it will also necessary fit the less restricted model. Therefore, substantive reasons and parsimony should also factor into model comparison. 
Hulland, 1999). These restraints are even more formidable in the case of hierarchical models. As far as identification of higher-order factor models is concerned it is required that for one higher-order factor there should be at least four lower-order factors, for orthogonal higherorder factors there should be at least three lower-order factors, while for oblique higher-order factors there should be at least two lower-order factors (Marsh and Hocevar, 1985; Rindskopf and Rose, 1988). Moreover, as far as the manifest variables for the lower-order factors are concerned at least two manifest variables are desired (Rindskopf and Rose, 1988). Except for mathematical identification the higher-order model is also susceptible to empirical underidentification (Dillon et al., 1987; Rindskopf, 1984; Rindskopf and Rose, 1988). Empirical underidentification might lead to inadmissible solutions and/or nonconvergence, especially as factor correlations might be "very close" to zero or one (Dillon et al., 1987; Rindskopf, 1984; Rindskopf and Rose, 1988).

The majority of SEM applications in the behavioral sciences employ the maximum likelihood (ML) estimation procedure to provide parameter estimates for the hypothesized models (Bollen 1989; Breckler 1990). However, the ML estimator exhibits desirable statistical properties (being unbiased, consistent, asymptotically efficient and approximating a $\chi 2$ distribution) only if several important assumptions are met (Bollen 1989; West, Finch, and Curran 1995). Chief among these is the assumption that the manifest variables follow a multivariate normal distribution. However, this assumption frequently does not hold in behavioral research (DeCarlo, 1997; Micceri 1989), as for example in most customer satisfaction and service quality research (Brown, Churchill Jr., and Peter 1993; Peterson and Wilson 1992).

As a consequence of the deviation from multivariate normality, the $\chi^{2}$ statistic does no longer provide an adequate assessment of model fit and leads to an underestimation of the standard error of the estimates in confirmatory factor analysis models (Curran, West, and 
Finch 1996; Hu, Bentler, and Kano 1992; West, Finch, and Curran 1995). Several alternatives to ML in case of nonnormality have been proposed (cf. West, Finch, and Curran 1995). Basically, two alternative estimation procedures have received widespread attention in the extant literature and have been employed in several simulation studies: (1) the asymptotically distribution free (ADF) estimator (Browne 1984) and the Satorra-Bentler -scaled $\chi^{2}$ statistic $\left(X_{S B}^{2}\right)$ with robust standard errors (Satorra and Bentler 1994). As far as the ADF estimation procedure is concerned, two major shortcomings for practical applications can be identified. First, the ADF estimator requires a relatively large sample size; Curran et al. (1996) report that a sample size of 1000 might be required for relatively simple models under typical conditions of nonnormality, while Hu et al. (1992) indicate that a sample size of 5000 might be needed with more complex models and under conditions of severe nonnormality (or both). Second, the ADF estimator is computationally quite intensive, even with the current generation of PC's (Bentler 1990; West, Finch, and Curran 1995). Several studies using Monte Carlo simulations found that the SB-scaled $\chi^{2}$ statistic with robust standard errors outperformed ADF, especially at smaller sample sizes under nonnormality, and even under normality conditions (Chou, Bentler, and Satorra 1991; Curran, West, and Finch 1996; Hu, Bentler, and Kano 1992).

The above problems might entirely be avoided by using components-based SEM, or PLS (Chin, 1998; Falk and Miller, 1992; Fornell and Bookstein, 1982;). Essentially, PLS allows for the conceptualisation of higher-order factors by repeated use of manifest variables (Lohmöller, 1989; Guinot et al., 2001; Tenenhaus et al., 2005; Wold, 1982). A higher-order factor can thus be created by specifying a latent variable which represents all the manifest variables of the underlying lower-order factors. For example, if a second-order construct consists of four underlying first-order factors each with three indicators, then the second order factor can be specified using all indicators (i.e. twelve indicators) of the underlying first order 
indicators. Obviously, this approach can easily be extended to higher order factors. An illustration of the PLS Path modeling approach to estimating parameters in a second-order factor model is depicted in Figure 3.

\section{[INSERT FIGURE 3 ABOUT HERE]}

\section{MEASUREMENT MODEL}

In order to assess the psychometric properties of the measures we initially specified a null model, in which no structural relationships are included. To assess the reliability of the measures we calculated the composite scale reliability (Chin, 1998; Fornell \& Larcker, 1981; Werts, Linn \& Jöreskög, 1974) and average variance extracted (Chin, 1998; Fornell \& Larcker, 1981). As can be seen in Table 1, composite scale reliabilities (CR) exceeded a value of 0.80 and the average variance extracted (AVE) of all measures compellingly exceeded the cut-off value of 0.50 proposed by Fornell and Larcker (1981) as the lowest AVE was 0.61 in the null model. In Table 3 the CRs and AVE of the measures in the second, third and fourth order models are included, also demonstrating CRs equal to or exceeding 0.80 and AVE all larger than 0.65 providing evidence for reliable measurements.

\section{[INSERT TABLE 1 ABOUT HERE]}

Moreover, as can be seen in Table 2, the square root of the average variance extracted exceeded the intercorrelations of the construct with the other constructs in the model indicating discriminant validity (Barclay et al., 1995; Chin, 1998). Moreover, inspection of the Theta $(\Theta)$ matrix containing the correlations between the residual terms $(<|0.2|)$ provided additional support for discriminant validity (Falk and Miller, 1992; Fornell and Bookstein, 1982). 


\section{TEST OF HIERARCHICAL STRUCTURE}

We used PLS Graph 3.0 (Chin, 2001) to estimate the parameters in the hierarchical model and the substantive model using partial least squares (PLS) estimation. ${ }^{5}$

\section{[INSERT TABLE 3 ABOUT HERE]}

As can be observed from Table 3 that the loadings of the first-order factors on the secondorder factors exceed 0.8 (Aesthetics: 0.91 [Visual Appeal] and 0.91 [Entertainment]; Playfulness: 0.95 [Escapism] and 0.90 [Enjoyment]; Customer ROI: 0.81 [Efficiency] and 0.83 [Economic Value]. These findings provide empirical support for hypotheses $\mathrm{H}_{1 \mathrm{a}}-\mathrm{H}_{1 \mathrm{f}}$. Similarly, the loadings of the second-order factors on the third-order factors are equal to or exceed 0.80 . These results provide empirical evidence for hypotheses $\mathrm{H}_{2 \mathrm{a}}-\mathrm{H}_{2 \mathrm{~d}}$. Finally, the loading of hedonic (intrinsic) value on experiential value equals 0.926 and the loading of utilitarian (extrinsic) value on experiential value is 0.780 , providing support for the fourth order model of experiential value expressed in hypotheses $\mathrm{H}_{3 a}-\mathrm{H}_{3 b}$. We used bootstrapping (Chin, 1998; Efron and Tibshirani, 1993) as implemented in PLS-Graph 3.0 with 250 replications and individual sign preprocessing (Chin, 2001) to obtain estimates for the standard errors of the estimates for parameters in the measurement (outer) model and the

\footnotetext{
Inspection of univariate measures of skewness and kurtosis showed only slight deviations from univariate normality $(<|1.0|)$. However, Mardia's test of multivariate kurtosis (Mardia, 1970; Normalized: 9.12 $(p<0.001)$ and Small's test of multivariate normality $(\mathrm{VQ} 3=246.55(\mathrm{p}<0.001)$ demonstrated that the assumption of multivariate normality was violated (DeCarlo, 1997). Consequently, we decided to opted for estimating the parameters in the model using MLM estimation in MPlus (Muthén and Muthén, 1998) in order to obtain the Satoora-Bentler-scaled $\chi^{2}\left(\chi^{2}(\mathrm{SB})\right)$ and the adjusted standard errors of the estimate. Our results for the first-order model showed a good fit to the data: $\chi^{2}(\mathrm{SB})_{131}=245.48,(\mathrm{p}<0.001)$, $\mathrm{CFI}=0.92 ; \mathrm{TLI}=0.90, \mathrm{RMSEA}=0.070$. However, inspection of the factor correlation revealed one correlation $>0.95$ and one factor correlation $<0.1$. Attempts to estimate the second-order model yielded an improper solution.
} 
structural (inner) model (hierarchical and substantive model). Our results indicated that all loadings were significant at $\alpha=0.01$.

\section{TESTING EXPERIENTIAL VALUE AS A DRIVER OF E-LOYALTY}

In testing the hypotheses in the substantive model $\left(\mathrm{H}_{4 \mathrm{a}}\right.$ to $\mathrm{H}_{4 \mathrm{~d}}$ and $\left.\mathrm{H}_{5}\right)$ we found support for four out of five hypotheses. We found a strong, positive effect of both hedonic (intrinsic) value $\left(\mathrm{H}_{4 \mathrm{a}}: \beta=0.49^{* *}\right)$ and utilitarian (extrinsic) value $\left(\mathrm{H}_{4 \mathrm{~b}}: \beta=0.38^{* *}\right)$ on attitudinal loyalty $\left(\mathrm{R}^{2}=0.56\right)$. However, we could not find support for the effect of hedonic (intrinsic) value on behavioral loyalty $\left(\mathrm{H}_{4 \mathrm{c}}: \beta=0.09\right)$, while utilitarian (extrinsic) value does have an effect on behavioral loyalty $\left(\mathrm{H}_{4 \mathrm{~d}}: \beta=0.14 *\right)$. Moreover, from Table 3 a strong positive relationship between attitudinal loyalty and behavioral loyalty $\left(\mathrm{H}_{5}: \beta=0.50^{* *}\right)$ can be observed $\left(\mathrm{R}^{2}=0.42\right)^{6}$. Moreover, using an incremental F-test we tested whether attitudinal loyalty is fully-mediating the relationship between intrinsic and extrinsic value and behavioral loyalty (Cohen and Cohen, 1983). Our results reveal that with $\alpha=0.05$ the direct effects of intrinsic value and extrinsic value on behavioral loyalty do not contribute significantly to $R^{2}\left(F_{(3,184)}=2.60\right.$, $\mathrm{p}=0.054)$.

\section{DEVELOPING A CUSTOMER TYPOLOGY}

The standardized latent variable scores (Tenenhaus et al., 2005; Wold, 1985) of the seven first-order factors (visual appeal, entertainment, escapism, enjoyment, service excellence, efficiency, and economic value) were obtained from PLS-Graph 3.0 and were used to conduct clustering analysis to identify customer segments based on sources of experiential value. We

The average $\mathrm{R}^{2}$ of the endogenous variables in the structural model and the average communality in the measurement model can be employed to calculate a global goodness-of-fit criterion (GOF; Tenenhaus et al., 2005). In our study GOF shows to have a value of 0.6184. If we assume a minimum AVE of 0.5 (Fornell and Larcker, 1981) and average medium effect size of 0.09 (Cohen, 1988) GOF would offer us a baseline value of 0.21 . 
used a two step-approach utilizing the results of hierarchical cluster analysis as input to nonhierarchical cluster analysis (Punj and Stewart 1983). We employed the CLUSTER procedure implemented in SAS Release 9 (Khattree and Naik, 2000) to conduct a hierarchical cluster analysis using Ward's minimum variance method with squared Euclidian distance as distance measure (Ward, 1963). There are no completely satisfactory methods (or stopping rules) to determine the number of clusters. Milligan and Cooper (1985) report that the pseudo F-statistic suggested by Calinski and Harabasz (1974) and the pseudo $\mathrm{t}^{2}$-statistic related to the $\mathrm{J}_{\mathrm{e}}(2) / \mathrm{J}_{\mathrm{e}}(1)$ statistic suggested by Duda and Hart (1973) performed well. We plotted the pseudo F-statistic, the pseudo t2-statistic and the fusion coefficients (Between Sum of Squares for Ward's minimum variance method) against the number of clusters. Inspection of these plots indicated four clusters for the data in our study. The centroids of these initial studies were employed as starting seeds using squared Euclidian distance as distance measure for the kmeans clustering algorithm implemented in the FASTCLUS procedure in SAS Release 8 (Khattree and Naik, 2000). The FASTCLUS procedure uses a method which is referred to as nearest centroid sorting (Anderberg, 1973). The cluster results are summarized in Table 4.

Our findings indicate that the clusters are differentiated in their mean values on the underlying value drivers. Based upon the differences that emerged from this analysis, the four clusters are labeled: hedonists, utilitarians, active negativists, reactive positivists. Hedonists exhibit positive means on the variables representing hedonic value (entertainment, escapism and enjoyment) with an exception of a slightly negative mean for visual appeal (-0.022). The hedonists do not seem to value the utilitarian aspects of experiential value represented by the negative means on the variables representing utilitarian value (service excellence, efficiency, economic value). Utilitarians represent the opposite customer segment by expressing appreciation for the utilitarian aspects, while valuing the hedonic aspects negatively (visual appeal is an exception again). Active negativists represent a group of individuals who reveal 
negative mean scores for all the variables, while we note that the means for the active variables (escapism, enjoyment, efficiency and economic value) are less negative than the means for the reactive variables (visual appeal, entertainment, and service excellence) (see also Figure 1). Reactive positivists seem to represent the opposite customer segment of the latter, since they value all aspects in a positive way expressing the highest means for the reactive value sources entertainment and service excellence. Visual appeal appears to be an exception again since it is defined as a reactive value source, while the mean score is comparable to the active sources for the final cluster.

\section{[INSERT TABLE 4 ABOUT HERE]}

We used the Games-Howell procedure for multiple comparisons to test the difference among the clusters (Games and Howell, 1976). This procedure maintains the family-wise error rate close to the chosen $\alpha$ for equal and unequal variances and equal and unequal sample sizes (Toothaker, 1993). Table 4 demonstrates that all four clusters differ significantly from each other on the factor entertainment. Most of the clusters also differ significantly on the other factors (the exceptions are indicated). These findings strengthen our cluster solution, demonstrating that each of the four clusters represents customers who value visual appeal, entertainment, escapism, enjoyment, service excellence, efficiency and economic value differently from the other three clusters, having important implications for online retailers.

\section{DISCUSSION AND CONCLUSION}

The main objective of this study was to provide empirical evidence for the third and fourth order latent model of experiential value, demonstrating that experience-based value in an online context consists of a hedonic (intrinsic) and utilitarian (extrinsic) value component. 
While Mathwick, Malhotra, and Rigdon’s (2001; 2002) provided conceptual support for a third and fourth order model, they only tested the second order model. Based on a sample of 190 website visitors reporting on the online book and CD store they visit most frequently, our PLS results go beyond existing research and provide strong empirical support for the third and fourth order latent model emphasizing the hedonic and utilitarian value components in the experiential value concept. Our findings demonstrate that interactions in an online environment consist of both a "fun" dimension as well as a "task-related" dimension, which is in line with findings in an offline context by Babin, Darden and Griffin (1994) who demonstrated that shopping value in an offline environment consists of a hedonic and utilitarian dimension.

The second aim of this paper was to assess the impact of hedonic and utilitarian value on consumers' attitudinal and behavioral e-loyalty. Mathwick et al. (2001) tested the impact of the second order experiential value factors (aesthetics, playfulness, service excellence, and customer return on investment) on attitudinal loyalty and their empirical support was mixed. They did not test the effect of these factors on behavioral loyalty, but rather focused on the impact of attitude on behavior (in terms of intention) and found strong support. Although their findings provide initial support for Homer and Kahle's (1988) value-attitude-behavior hierarchy our study empirically tested a more comprehensive model of experiential value and the impact of the third order factors hedonic (intrinsic) and utilitarian (extrinsic) value on both attitudinal as well as behavioral loyalty. The PLS results of our sample of visitors of book and CD websites demonstrate that hedonic value as well as utilitarian value impact attitudinal loyalty, while only utilitarian value impacts behavioral loyalty. Hence, consumers who appreciate the efficiency aspects of online shopping as well as consumers who appreciate the entertainment dimensions of their favorite Internet site reveal an increased level of preference 
for their favorite site. Nevertheless, only utilitarian value directly impacts behavioral loyalty intentions positively. Apparently, visitors driven by a more goal directed value dimension translate their need directly to their intended behaviors, while the visitors valuing the entertainment aspects express their value in terms of attitude rather than behavioral intentions. In line with Mathwick et al. (2001) we also found strong support for the positive influence of attitude on behavioral intentions.

Finally, the purpose of our study was to develop a customer typology based on the experiential value dimensions. In an offline environment, Reynolds and Beatty (1999) developed a customer typology including for instance shopping lovers and shopping haters. In an online context Sheehan (2002) discusses passionates, pragmatics, and phobics as different groups of Internet users. Kau et al. (2003) provided clusters of shoppers and surfers referring to segments such as comparative shoppers versus traditional shoppers. Mathwick (2002) also developed a typology of online shoppers. However, she did not use her scale of experiential value to distinguish the clusters, but rather relied on relational norms and behavior leading to four segments labeled transactional community members, socializers, lurkers, and personal connectors. Extending the studies described, our results demonstrate that customers of online book and CD stores differ with respect to the factors that contribute to the experiential value they perceive. Our first cluster, hedonists mainly appreciate the entertainment, escapism and enjoyment aspects of a website. Their negative evaluation of visual appeal is contrary to our expectations, but a potential explanation might be that the previous three factors really refer to an experience, while visual appeal is merely aesthetics. The utilitarian customers are likely to have a clear objective when shopping and therefore value the utilitarian aspects such as service excellence, efficiency, and economic value, smoothing their shopping process. The third segment we distinguished consists of the active negativists referring to the fact that they 
are negative on all the aspects, nevertheless value the active elements escapism, enjoyment, efficiency and economic value somewhat less negatively. Apparently these customers do not value the online shopping environment, although they have a slight preference for active rather than reactive elements in the experience. And finally the reactive positivist, represent the opposite type of customer, who is basically positive about all the elements in the online experience, and slightly more so on the reactive elements entertainment and service excellence. Again visual appeal (reactive) is an exception, as we would expect a higher value, strengthening our previous potential explanation. Our post hoc analysis demonstrated that the four clusters almost without exception differ significantly from each other with respect to the first order factors of experiential value, clearly representing different types of customers.

\section{Limitations and suggestions for future research}

As the main objective of this study was to test the hierarchical structure of experiential value as a potential driver of e-loyalty, the study has excluded the impact of more traditional antecedents such as satisfaction and trust on loyalty (e.g. Chiou 2004; Harris and Goode 2004). An interesting avenue for future research would be to include experiential value next to additional drivers of e-loyalty to assess its relative importance.

Additional work could be undertaken regarding individual difference variables moderating the effect of experiential value on e-loyalty. For example need for cognition (Cacioppo and Petty 1982) and need for affect (Sojka and Giese 1997) and sociability (Reynolds and Beatty 1999) could potentially strengthen or weaken the impact of the hedonic and utilitarian dimensions on e-loyalty.

Future research could also reduce common method bias, by employing an experimental technique and manipulating experiential value, while measuring e-loyalty by means of selfreported measures. It is also plausible that the impact of hedonic and utilitarian value sources 
differ across context. Future research should consider an assessment of extreme settings in terms of their value orientation. For example comparing a career site (utilitarian value) with a mobile phone fun club (hedonic value) could lead to insightful findings. 


\section{References}

Arnold, Mark J. and Kristy E. Reynolds. 2003. "Hedonic Shopping Motivations.” Journal of Retailing 79: 77-95.

Aldenderfer, Mark. S., and Roger. K. Blashfield. 1984. Cluster Analysis. Newbury Park, CA: Sage Publications.

Anderberg, Michael.R. 1973. Cluster Analysis for Applications. New York: Academic Press, Inc.

Babin, Barry J., William R. Darden, and Mitch Griffin. 1994. "Work and/or Fun: Measuring Hedonic and Utilitarian Shopping Value.” Journal of Consumer Research 20 (Spring): 644-656.

Bentler, Peter M. 1990.”Comparative fit Indices in Structural Models.” Psychological Bulletin, 107 (2): 238-246.

Bollen, Kenneth A. 1989. Structural Equations with Latent Variables. New York: Wiley.

Breckler, Steven J. 1990. "Application of Covariance Structure Modelling in Psychology: Cause for Concern?" Psychological Bulletin 107 (2): 260-273.

Brown, Tom J., Gilbert A. Churchill Jr., and J. Paul Peter 1993. "Improving the Measurement of Service Quality." Journal of Retailing 69 (1): 127-39.

Cacioppo, John T. and Richard E. Petty, 1982. “The Need for Cognition.” Journal of Personality and Social Psychology, 42: 116-131.

Calinski T. and J. Harabasz 1974. "A dendrite method for cluster analysis.” Communications in Statistics, 3, 1-27.

Chaudhuri, Arjun. and Morris.B. Holbrook. 2001. "The Chain of Effects from Brand Trust and Brand Affect to Brand Performance: the Role of Brand Loyalty." Journal of Marketing, 65 (2): 81-93. 
Childers, Terry L., Chresrwher L. Carr, Joann Peck, and Stephen Carson. 2001. "Hedonic and Utilitarian Motivations for Online Retail Shopping Behavior.” Journal of Retailing 77 (Winter): 511-535.

Chin, Wynne.W. 1998. "The Partial Least Squares Approach to Structural Equation Modeling.” In: Modern Business Research Methods. Eds. Marcoulides, G.A., Mahwah, NJ: Lawrence Erlbaum Associates, 295-336.

Chin, Wynne.W. 2001. PLS-Graph User's Guide Version 3.0. Houston, TX: C.T. Bauer College of Business, University of Houston.

Chiou, Jyh-Shen. 2004. “The Antecedents of Consumers' Loyalty toward Internet Service Providers.” Information \& Management 41, (6): 685-695.

Chou, Chih-Ping, Peter M. Bentler, and Albert Satorr. 1991. "Scaled Test Statistics and Robust Standard Errors for Nonnormal Data in Covariance Structure Analysis: A Monte Carlo Study." British Journal of Mathematical and Statistical Psychology 44: $347-357$.

Cohen, Jacob and Patricia Cohen. 1983. Applied Multiple Regression/Correlation Analysis for the Behavioral Sciences. Hillsdale: Lawrence Erlabaum Associates.

Cotte, June., Tilottama G. Chowdhury, S. Ratneshwar, and Lisa M. Ricci, 2005. "Pleasure or Utility? The Role of time Planning Style in Web Usage Benefits and Behaviors." Working Paper, University of Western Ontario.

Csikszentmihalyi, Mihaly.1997. Finding Flow: The Psychology of Engagement with Everyday Life. New York: Basic Books.

Curran, Patrick J., Stephan G. West, and John F. Finch. 1996. "The Robustness of Test Statistics to Nonnormality and Specification Error in Confirmatory Factor Analysis." Psychological Methods 1: 16-29. 
Dahlén, Micael and Fredrik Lange. 2002. "Real Consumers in the Virtual Store." Scandinavian Journal of Management 18: 341-363.

Davis, Fred.D., 1989. "Perceived Usefulness, Perceived Ease of Use, and User Acceptance of Information Technology.” MIS Quarterly 13 (3): 319-340.

DeCarlo, Lawrence T. 1997. "On the Meaning and Use of Kurtosis." Psychological Methods, 2 (3): 292-307.

Dillon, William R., Ajith Kumar, and Narendra Mulani. 1987. "Offending Estimates in Covariance Structure Analysis: Comments on Causes and Solutions to Heywood Cases.” Psychological Bulletin 101 (Winter): 126-135.

Duda Richard O. and Peter E. Hart. 1973. Pattern Classification and Scene Analysis. New York: Wiley, 1973.

Edwards, Jeffrey R. 2001. "Multidimensional Constructs in Organizational Behavior Research: An Integrative Analytical Framework.” Organizational Research Methods 4 (2): 144-192.

Edwards, Jeffrey R. and Richard P. Bagozzi. 2000. "On the Nature and Direction of the Relationship between Constructs and Measures." Psychological Methods 5 (Summer): $155-174$.

Efron, Bradley and Robert J. Tibshirani. 1993. "An Introduction to the Bootstrap." Monographs on Statistics and Applied Probability. 57. New York: Chapman and Hall.

Emmanouilides, Christos. and Kathy. Hammond, 2000. "Internet Usage: Predictors of Active Users and Frequency of Use.” Journal of Interactive Marketing, 14 (2), 17-32.

Falk, R. Frank and Nancy. B. Miller. 1992. A Primer for Soft Modeling. Akron, OH: University of Akron Press. 
Fornell, Claes and Fred L. Bookstein. 1982. “Two Structural Equations Models: LISREL and PLS applied to Consumer Exit-Voice Theory.” Journal of Marketing Research 19: 440452.

Fornell, Claes and David F. Larcker. 1981. "Evaluating Structural Equation Models with Unobservable Variables and Measurement Error." Journal of Marketing Research 18: $39-50$.

Games Paul A. and James F. Howell. 1976. "Pairwise multiple comparison procedures with unequal n's and/or variances." Journal of Educational Statistics 1: 113-125.

Gans, Noah. 2002. "Customer Loyalty and Supplier Quality Competition.” Management Science 48 (2): 207-221.

Guinot, Christiane, Julie Latreille, and Michel Tenenhaus. 2001. "PLS Path Modeling and Multiple Table Analysis. Application to the Cosmetic Habits of Women in Ile-deFrance." Chemometrics and Intelligent Laboratory Systems 58: 247-259.

Harris, Lloyd C. and Mark M.H. Goode. 2004. "The Four Levels of Loyalty and the Pivotal Role of Trust: A Study of Online Service Dynamics.” Journal of Retailing 80: 139-158.

Havlena, William J. and Morris B. Holbrook. 1986. "The Varieties of Consumption Experience: Comparing Two Typologies of Emotion in Consumer Behavior.” Journal of Consumer Research 13 (Winter): 394-404.

Hirschman, Elizabeth C. and Morris B. Holbrook. 1982. "Hedonic Consumption: Emerging Concepts, Methods and Propositions.” Journal of Marketing 46 (3): 92-101.

Hoffman, Donna L. and Thomas P. Novak. 1996. "Marketing in Hypermdia ComputerMediated Environments: Conceptual Foundations.” Journal of Marketing 60: 50-68.

Holbrook, Morris B. 1994. "The Nature of Customer Value: An Axiology of Services in the Consumption Experience.” In Service Quality: New Directions in Theory and Practice. Eds. Roland T. Rust and Richard L. Oliver. CA: Newbury Park, Sage Publications, 2171. 
Holbrook, Morris B. and Elizabeth C. Hirschman. 1982. "The Experiential Aspects of Consumption: Consumer Fantasies, Feelings, and Fun.” Journal of Consumer Research 9: 132-140.

Homer, Pamela M. and Lynn R. Kahle. 1988. "A Structural Equation Test of the ValueAttitude-Behavior Hierarchy." Journal of Personality and Social Psychology 54 (4): 638-646.

Hu, Li-tze, Peter M. Bentler, and Yutaka Kano. 1992. "Can Test Statistics in Covariance Structure Analysis Be Trusted?" Psychological Bulletin 112: 351-362.

Kau, Ah K., Yingchan E. Tang, and Sanjoy Ghose. 2003. "Typology of Online Shoppers.” Journal of Consumer Marketing 20 (2): 139-156.

Khattree, Ravindra. and Dayanand N. Naik 2000. Multivariate Data Reduction and Discrimination. Cary, NC: SAS Institute, Inc.

Kim, Soyoung and Leslie Stoel. 2004. "Dimensional Hierarchy of Retail Website Quality." Information \& Management 41: 619-633.

Korgaonkar, Pradeep K., Daulat Lund and Barbara Price. 1985. "A Structural Equations Approach Toward Examination of Store Attitude and Store Patronage Behavior." Journal of Retailing 61 (2): 39-60.

Korgaonkar, Pradeep K. and Lori D. Wolin, 1999. "A Multivariate Analysis of Web Usage.” Journal of Advertising Research, 39 (March/April), 53-68.

Kwak, Hyokjin, Richard J. Fox, and George M. Zinkhan. 2002. "What Products can be Successfully Promoted and Sold via the Internet?." Journal of Advertising Research 42 (1) 23-38.

Law, Kenneth S. and Chi-Sum Wong. 1999. "Multidimensional Constructs in Structural Equation Analysis: An Illustration Using the Job Perception and Job Satisfaction Constructs." Journal of Management 25 (2): 143-160. 
Law, Kenneth S., Chi-Sum Wong and William H. Mobley. 1998. "Toward a Taxonomy of Multidimensional Constructs.” Academy of Management Review 23 (4): 741-755.

Lohmöller, Jan-Bernd 1989. Latent Variable Path Modeling with Partial Least Squares. Heidelberg: Germany: Physica-Verlag.

Luo, Xueming and Mojtaba. Seyedian. 2004. "Contextual Marketing and CustomerOrientation Strategy for E-Commerce: An Empirical Analysis.” International Journal of Electronic Commerce 8 (2): 95-188.

Mardia, Kanti. V. 1970. "Measures of Multivariate Skewness and Kurtosis with Applications.” Biometrika, 57: 519-530.

Marsh, Herbert W and David Hocevar. 1985. "The Application of Confirmatory Factor Analysis to the Study of the Self-Concept: First and Higher Order Factor Structures and their Invariance across Age Groups.” Psychological Bulletin. 97: 562-582.

Mathwick, Charla., Naresh Malhotra and Edward Rigdon. 2001. "Experiential Value: Conceptualization, Measurement and Application in the Catalog and Internet Shopping Environment.” Journal of Retailing 77: 39-56.

Mathwick, Charla. 2002. "Understanding the Online Consumer: A Typology of Online Relational Norms and Behavior.” Journal of Interactive Marketing 16: 40-55.

Mathwick, Charla., Naresh Malhotra and Edward Rigdon. 2002. "The Effect of Dynamic Retail Experiences on Experiential Perceptions of Value: An Internet and Catalog Comparison.” Journal of Retailing 78 (1): 51-61.

Micceri, Theodore. 1989. "The Unicorn, the Normal Curve, and Other Improbable Creatures.” Psychological Bulletin 105: 156-166.

Milligan, Glenn W. and Martha C. Cooper. 1985. “An Examination of Procedures for Determining the Number of Clusters in a Data Set.” Psychometrika 50: 159 -179. 
Morgan, Robert M. and Shelby D. Hunt. 1994. "The Commitment-Trust Theory of Relationship Marketing.” Journal of Marketing 58 (3): 20-38.

Nielsen, Jakob. 1997. "Loyalty on the Web.” Alertbox, August: 1-3.

Novak, Thomas P., Donna L. Hoffman, and Yiu-Fai Yung. 2000. "Measuring the Customer Experience in Online Environments: A Structural Modeling Approach.” Marketing Science 19 (1): 22-42.

Novak, Thomas P., Donna L. Hoffman, and Adam Duhacheck, 2003. "The Influence of GoalDirected and Experiential Activities on Online Flow Experiences." Journal of Consumer Psychology 13 (1/2): 3-16.

Oliver, Richard. L. 1997. Satisfaction. A Behavioral Perspective on the Consumer. New York: McGraw-Hill.

Peterson, Robert A. 1995. "Relationship Marketing and the Consumer." Journal of the Academy of Marketing Science 23 (4): 278-281.

Peterson, Robert A. and William R. Wilson. 1992. "Measuring Customer Satisfaction: Fact and Artifact." Journal of the Academy of Marketing Science 20 (1): 61-71.

Punj, Girish and David W. Stewart. 1983. "Cluster Analysis in Marketing Research: Review and Suggestions for Application.” Journal of Marketing Research 20: 134-148.

Reichheld, Frederick F. and Phil Schefter. 2000. "E-loyalty: Your Secret Weapon on the Web." Harvard Business Review (July-August): 105-113.

Reynolds, Kristy E. and Sharon E. Beatty. 1999. "A Relationship Customer Typology." Journal of Retailing 75 (4): 509-523.

Rindskopf, David. 1984. "Structural Equation Models: Empirical Identification, Heywood Cases and Related Problems." Sociological Methods and Research. 13: 109-119.

Rindskopf, David and Ted. Rose. 1988. "Second Order Factor Analysis: Some Theory and Applications. Mulivariate Behavioral Research 23: 51-67. 
Rohm, Andrew J. and Vanitha Swaminathan. 2004. "A Typology of Online Shoppers based on Shopping Motivations.” Journal of Business Research 57: 748-757.

Satorra, Albert and Peter M. Bentler. 1994. "Corrections to Test Statistic and Standard Error in Covariance Structure Analysis," in Analysis of Latent Variables in Developmental Research. Eds. Alexander von Eye, et al., Newbury Park, CA: Sage Publications.

Scheraga, Dan. 2000. “Penney’s Net Advantage.” Chain Store Age: 114-118.

Sheehan, Kim B. 2002. "Of Surfing, Searching, and Newshounds: A Typology of Internet Users' Online Sessions.” Journal of Advertising Research: 62-71.

Sirdeshmukh, Deepak, Jagdip Singh, and Barry Sabol. 2002. "Consumer Trust, Value, and Loyalty in Relational Exchanges.” Journal of Marketing 66 (1): 15-38.

Sojka, Jane Z. and Joan L. Giese. 1997. "Thinking or Feeling: An Examination of Interaction between Processing Styles." Advances in Consumer Research 24: 438-442.

Srinivasan, Srini S., Rolf Anderson, and Kishore Ponnavlu. 2002. "Customer Loyalty in ECommerce: An Exploration of its Antecedents and Consequences." Journal of Retailing 78: 41-50.

Tenenhaus, Michel, Vincenzo E. Vinzi, Yves-Marie Chatelin and Carlo Lauro. 2005. "PLS Path Modeling." Computational Statistics \& Data Analysis 48: 159-205.

Toothaker, Larry E. 1992. Multiple Comparison Procedures. Sage University Paper Series on Quantitative Applications in the Social Sciences (07-089), Newbury Park, CA: Sage Publications.

Verona, Gianmario and Emanuela Prandelli. 2002. "A Dynamic Model of Customer Loyalty to Sustain Competitive Advantage on the Web.” European Management Journal 20 (3): 299-309. 
Voss, Kevin E., Eric R. Spangenberg, and Bianca Grohmann. 2003. "Measuring Hedonic and Utilitarian Dimensions of Consumer Attitude.” Journal of Marketing Research 40 (3): 310-320.

Ward, J.H. 1963. "Hierarchical grouping to optimize an objective function." Journal of the American Statistical Association. 58: 236-244

Werts, Charles E., Robert L. Linn, and Karl G. Jöreskög. 1974. "Intraclass Reliability Estimates: testing Structural Assumptions." Educational and Psychological Measurement 34: 25-33.

West, Stephan G., John F. Finch, and Patrick J. Curran.1995. "Structural Equation Model with Nonnormal Variables," in Structural Equation Modeling: Conceptes, Issues and Applications. Eds. Rick H. Hoyle. Thousand Oaks: Sage Publications.

Westbrook, Robert A. and William C. Black. 1985. "A Motivation-Based Shopper Typology.” Journal of Retailing 61: 78-103.

Wold, Herman. 1982. Soft Modeling: “The Basic Design and some Extensions,” In: Jöreskog, Karl G. and Herman Wold. Systems under Indirect Observation: Causality, Structure, Prediction, 2, Amsterdam: North Holland. 1-54.

Wold, Herman. 1985. Partial Least Squares. In: Encyclopedia of Statistical Sciences. Eds. Kotz, Samuel. and Norman. L. Johnson. 6. New York: Wiley, 581-591.

Wolfinbargar, Mary and Mary C. Gilly. 2003. "eTailQ: Dimensionalizing, Measuring and Predicting eTail Quality.” Journal of Retailing 79 (3): 183-199.

Woodruff, Robert B., 1997. "Customer Value: The Next Source for Competitive Advantage." Journal of the Academy of Marketing Science 25 (2): 139-153.

Zeithaml, Valarie A. 1988. "Consumer Perceptions of Price, Quality, and Value: A MeansEnd Model and Synthesis of Evidence.” Journal of Marketing 52 (3): 2-22. 
Figure 1: Hierarchical Model of Experiential Value

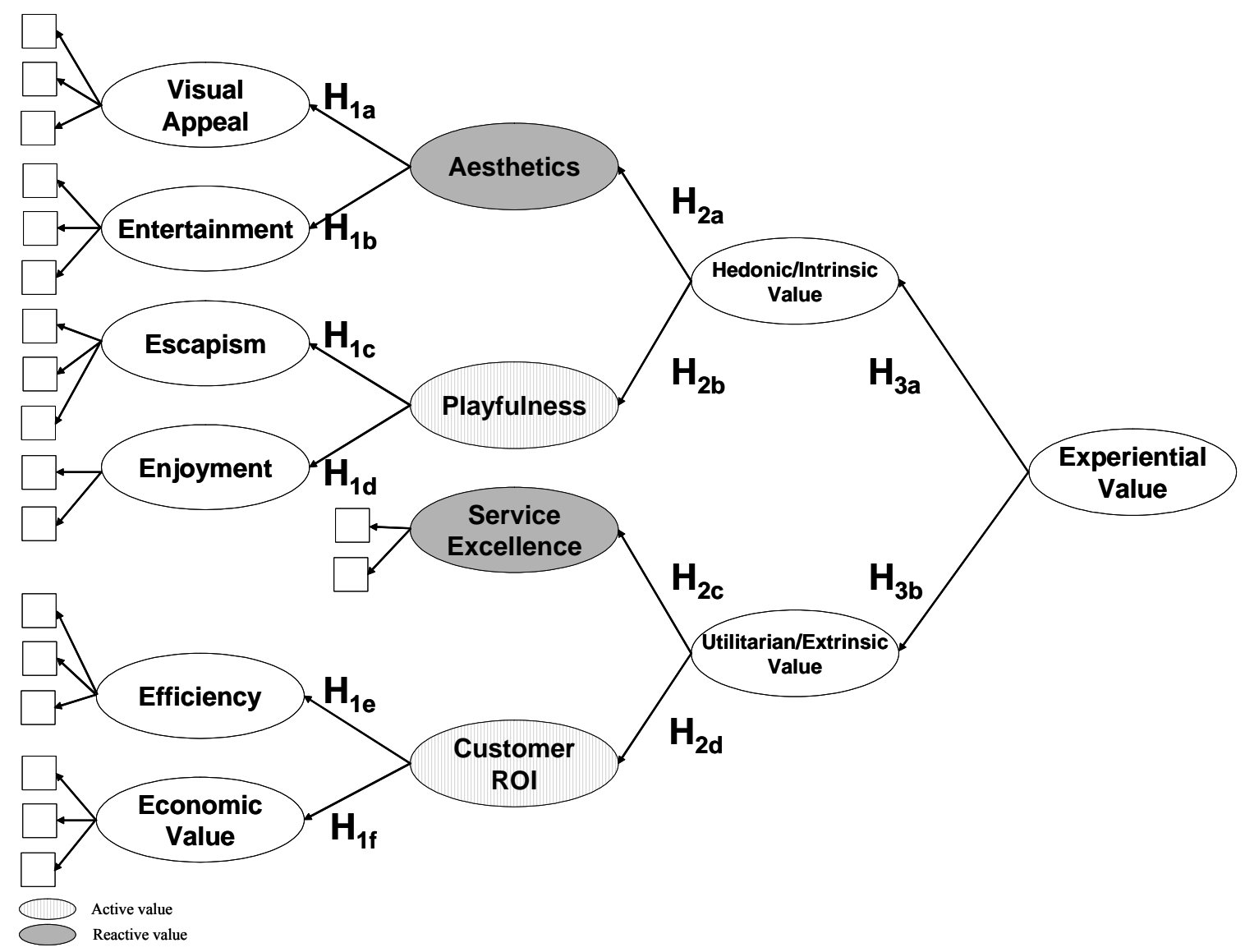


Figure 2: Conceptual Model

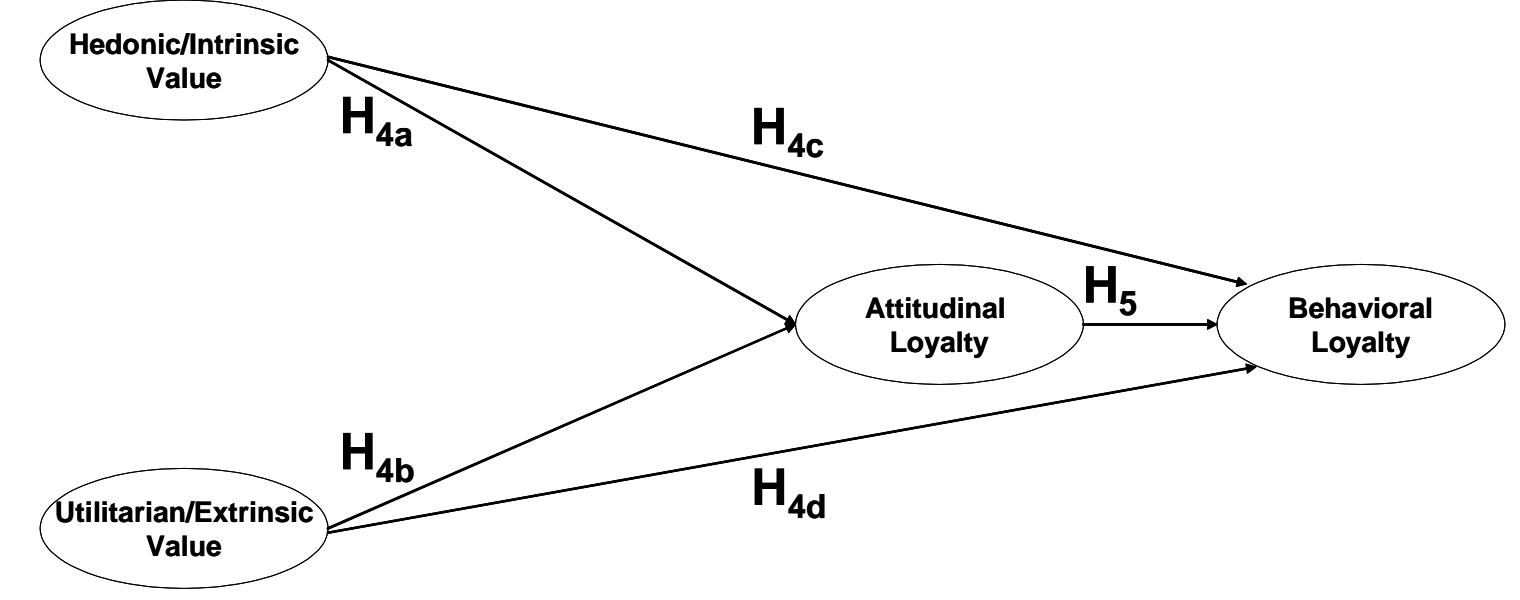


Figure 3: Second-Order Factor Model Using PLS Path Modelling

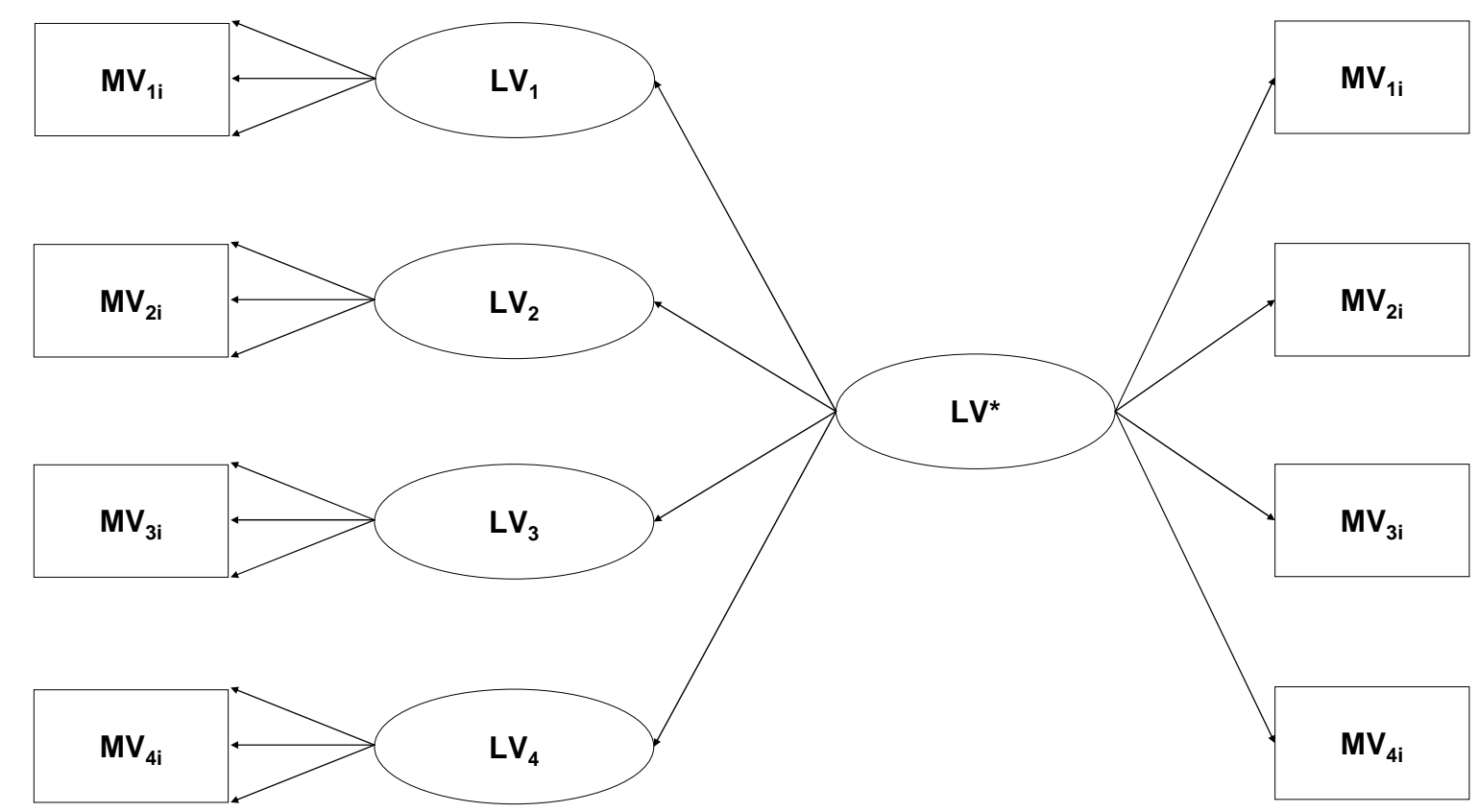


Table 1: Psychometric Properties in Null Model ${ }^{\text {a }}$

\begin{tabular}{|c|c|c|c|c|}
\hline Construct & Item & Loading & CR & AVE \\
\hline \multicolumn{5}{|c|}{ EXPERIENTIAL VALUE (Mathwick, Malhotra, and Rigdon, 2001) } \\
\hline \multirow{3}{*}{ Visual Appeal } & 1 The way $X$ displays its products is attractive & 0.82 & 0.90 & 0.75 \\
\hline & 2 X's Internet site is aesthetically appealing & 0.88 & & \\
\hline & 3 I like the way X's Internet site looks & 0.90 & & \\
\hline \multirow{3}{*}{$\begin{array}{l}\text { Entertainment } \\
\text { Value }\end{array}$} & 1 I think X's Internet site is very entertaining & 0.79 & 0.88 & 0.70 \\
\hline & $\begin{array}{l}2 \text { The enthusiasm of X's Internet site is catching, it picks } \\
\text { me up }\end{array}$ & 0.88 & & \\
\hline & $3 \mathrm{X}$ doesn't just sell products - it entertains me & 0.84 & & \\
\hline \multirow[t]{3}{*}{ Escapism } & $\begin{array}{l}1 \text { Shopping from X's Internet site "get's me away from it } \\
\text { all" }\end{array}$ & 0.76 & 0.85 & 0.65 \\
\hline & $\begin{array}{l}2 \text { Shopping from } X \text { makes me feel like I am in another } \\
\text { world }\end{array}$ & 0.80 & & \\
\hline & $\begin{array}{l}3 \text { I get so involved when I shop from } X \text { that I forget } \\
\text { everything else }\end{array}$ & 0.85 & & \\
\hline \multirow[t]{2}{*}{ Intrinsic Enjoyment } & $\begin{array}{l}1 \text { I enjoy shopping from X's Internet site for its own } \\
\text { sake, not just for the items I may have purchased }\end{array}$ & & 0.87 & 0.76 \\
\hline & $\begin{array}{l}2 \text { I shop from X's Internet site for the pure enjoyment of } \\
\text { it }\end{array}$ & 0.87 & & \\
\hline \multirow[t]{2}{*}{ Excellence } & 1 When I think of $X, I$ think of excellence & 0.87 & 0.86 & 0.76 \\
\hline & 2 I think of $X$ as an expert in the merchandise it offers & 0.87 & & \\
\hline \multirow[t]{3}{*}{ Efficiency } & $\begin{array}{l}\text { 1 Shopping from } X \text { is an efficient way to manage my } \\
\text { time }\end{array}$ & 0.80 & 0.84 & 0.64 \\
\hline & 2 Shopping from X's Internet site makes my life easier & 0.78 & & \\
\hline & 3 Shopping from X's Internet site fits with my schedule & 0.82 & & \\
\hline \multirow[t]{3}{*}{ Economic Value } & $1 \mathrm{X}$ products are a good economic value & 0.81 & 0.87 & 0.67 \\
\hline & 2 Overall, I am happy with X's prices & 0.87 & & \\
\hline & $\begin{array}{l}3 \text { The prices of the product(s) I purchased from X's } \\
\text { Internet site are too high, given the quality of the } \\
\text { merchandise }\end{array}$ & 0.80 & & \\
\hline \multicolumn{5}{|c|}{ E-LOYALTY (Srinivasan, Anderson and Ponnavolu 2002) } \\
\hline \multirow[t]{3}{*}{ Attitudinal Loyalty } & 1 I like using this website & 0.73 & 0.85 & 0.66 \\
\hline & $\begin{array}{l}2 \text { To me this is the best retail website to do business } \\
\text { with }\end{array}$ & 0.84 & & \\
\hline & 3 I believe that this is my favorite retail website & 0.87 & & \\
\hline \multirow[t]{3}{*}{ Behavioral Loyalty } & 1 I seldom consider switching to another website & 0.82 & 0.82 & 0.61 \\
\hline & $\begin{array}{l}2 \text { As long as the present service continues, I doubt that } \\
\text { I would switch to another website }\end{array}$ & 0.78 & & \\
\hline & $\begin{array}{l}3 \text { I try to use this website whenever I need to make a } \\
\text { purchase }\end{array}$ & 0.74 & & \\
\hline
\end{tabular}

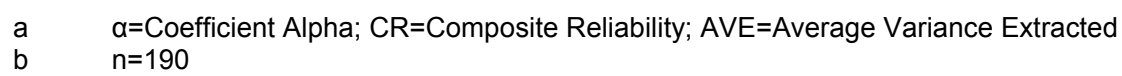


Table 2: Intercorrelations of the Latent Variables ${ }^{a, b}$

\begin{tabular}{|c|c|c|c|c|c|c|c|c|c|}
\hline Construct & 1. & 2. & 3. & 4. & 5. & 6. & 7. & 8. & 9. \\
\hline 1. Visual Appeal & 0.87 & & & & & & & & \\
\hline 2. Entertainment & 0.65 & 0.84 & & & & & & & \\
\hline 3. Escapism & 0.31 & 0.62 & 0.81 & & & & & & \\
\hline 4. Enjoyment & 0.27 & 0.57 & 0.70 & 0.87 & & & & & \\
\hline 5. Excellence & 0.59 & 0.56 & 0.37 & 0.38 & 0.87 & & & & \\
\hline 6. Efficiency & 0.32 & 0.26 & 0.21 & 0.20 & 0.46 & 0.80 & & & \\
\hline 7. Economic Value & 0.34 & 0.21 & 0.05 & -0.03 & 0.41 & 0.32 & 0.82 & & \\
\hline 8. Attitudinal Loyalty & 0.62 & 0.56 & 0.49 & 0.42 & 0.63 & 0.43 & 0.34 & 0.81 & \\
\hline 9. Behavioral Loyalty & 0.34 & 0.41 & 0.45 & 0.34 & 0.43 & 0.35 & 0.32 & 0.63 & 0.78 \\
\hline
\end{tabular}

a Square root of AVE on diagonal

b $\quad n=190$ 
Table 3: Testing the Hierarchical Model and the Hypotheses in the Substantive Model ${ }^{a}$

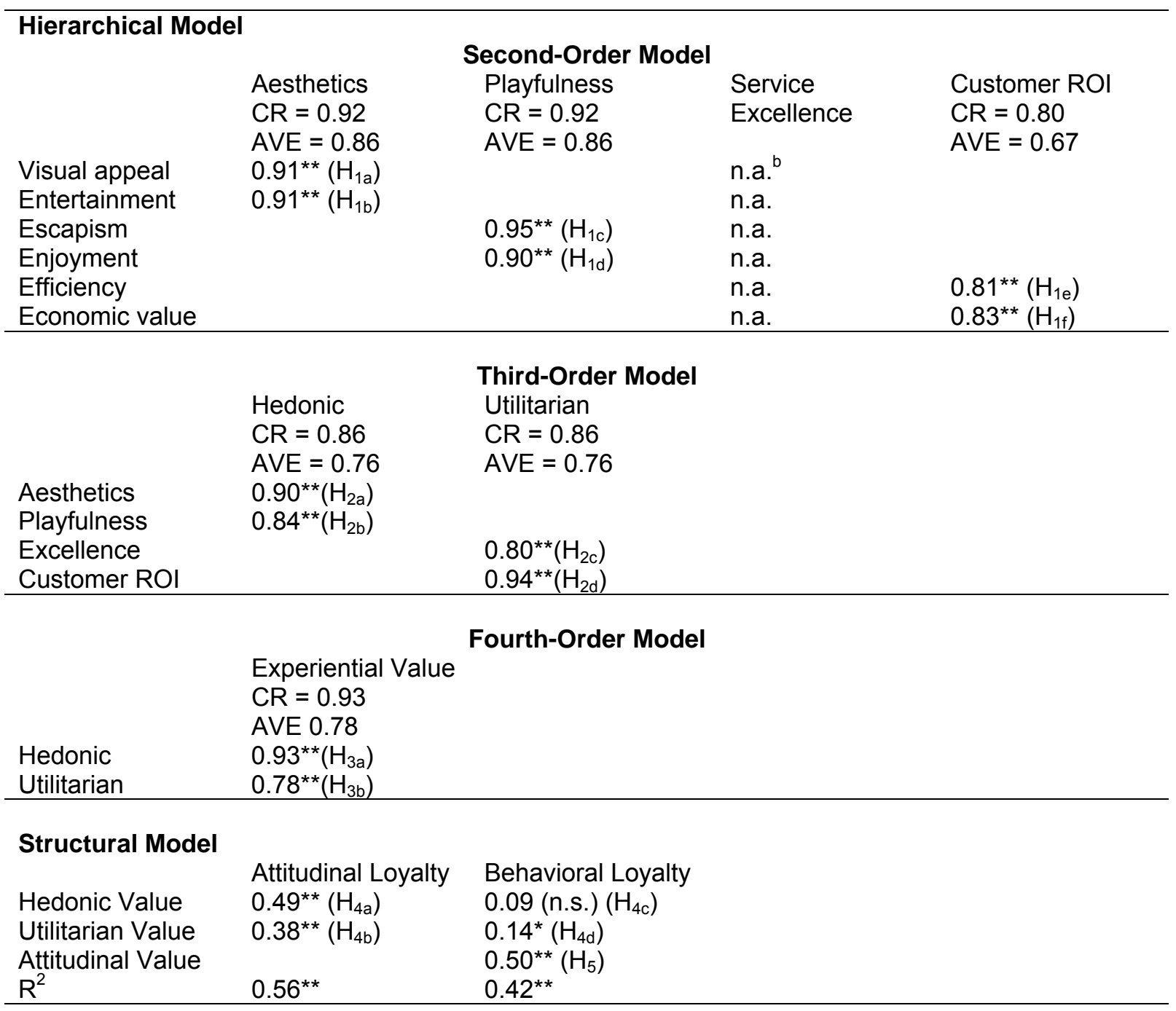

$*=p<0.05$

$* *=p<0.01$

n.s. = not significant

Service excellence is specified as a first-order factor in the null-model. However, in the hierarchical model service excellence constitutes a second-order factor. 
Table 4: Results of Nonhierarchical Cluster Analysis ${ }^{a, b}$

Third-order First-order Factors Final Cluster Centroids

Factors

\begin{tabular}{|c|c|c|c|c|c|}
\hline & & $\begin{array}{l}\text { Hedonists } \\
\qquad N=24\end{array}$ & $\begin{array}{l}\text { Utilitarians } \\
\qquad N=82\end{array}$ & $\begin{array}{c}\text { Active } \\
\text { Negativists } \\
\mathrm{N}=44\end{array}$ & $\begin{array}{c}\text { Reactive } \\
\text { Positivists } \\
N=38\end{array}$ \\
\hline $\begin{array}{l}\text { Hedonic Value } \\
\text { reactive }\end{array}$ & Visual Appeal & $-0.022^{A}$ & $0.251^{\mathrm{A}}$ & $-1.217^{B}$ & $0.880^{C}$ \\
\hline active & $\begin{array}{l}\text { Entertainment } \\
\text { Escapism } \\
\text { Enjoyment }\end{array}$ & $\begin{array}{l}0.601^{\mathrm{A}} \\
1.210^{\mathrm{A}} \\
1.313^{\mathrm{A}}\end{array}$ & $\begin{array}{l}-0.130^{B} \\
-0.446^{B} \\
-0.460^{B}\end{array}$ & $\begin{array}{l}-1.154^{\mathrm{C}} \\
-0.690^{\mathrm{B}} \\
-0.689^{\mathrm{B}}\end{array}$ & $\begin{array}{l}1.235^{\mathrm{D}} \\
0.998^{\mathrm{A}} \\
0.960^{\mathrm{A}}\end{array}$ \\
\hline \multirow{2}{*}{$\begin{array}{r}\text { Utilitarian Value } \\
\text { reactive } \\
\text { active }\end{array}$} & Service Excellence & $-0.144^{\mathrm{A}}$ & $0.042^{\mathrm{A}}$ & $-1.021^{B}$ & $1.185^{\mathrm{C}}$ \\
\hline & $\begin{array}{l}\text { Efficiency } \\
\text { Economic Value }\end{array}$ & $\begin{array}{l}-0.383^{\mathrm{A}} \\
-0.144^{\mathrm{A}}\end{array}$ & $\begin{array}{l}0.124^{B} \\
0.256^{B}\end{array}$ & $\begin{array}{l}-0.729^{A} \\
-0.574^{A}\end{array}$ & $\begin{array}{l}0.818^{C} \\
0.719^{C}\end{array}$ \\
\hline
\end{tabular}

a LV are standardized.

b Clusters with different superscripts are statistically significantly different at $\alpha=0.05$. 